\title{
Solutions of diesel drives for use in underground workings of hard coal mine
}

\author{
The examples of application of combustion engines for the mining machinery drive have been presented in the article. \\ The corresponding regulations concerned diesel combustion engines use in mines have been also presented. Moreover, \\ the new technical solutions in such type engines aiming at the use safety increase and the exhaust gas toxic components \\ emission decrease have been proposed.
}

Key words: combustion engine, mining machinery, law regulations, exhaust gas toxic components emission

\section{Rozwiązania napędów spalinowych do zastosowań w wyrobiskach podziemnych węgla kamiennego}

\author{
W artykule zaprezentowano przykłady zastosowania silników spalinowych do napędu maszyn w górnictwie. Przedsta- \\ wiono odpowiednie przepisy prawne dotyczace użytkowania silników spalinowych $w$ kopalniach. Ponadto zapropono- \\ wano nowe rozwiazania techniczne w tego typu silnikach zmierzające do zwiększenia bezpieczeństwa ich użytkowania \\ i zmniejszenia emisji toksycznych składników spalin.
}

Słowa kluczowe: silnik spalinowy, maszyny górnicze, przepisy prawne, emisja toksycznych składników spalin

\section{Introduction}

Transportation machines with diesel drive are used in the undergrounds of Polish hard coal mines from the end of 1970s and they replace or support battery, pneumatic and rope drives that were used so far. Both economic and social conditions, which force managing boards of collieries to maximal reduction of mining costs, decrease of work inconveniences and increase of work safety, are the reasons. The last aspect results mainly from elimination of dangerous machines with rope drive. Use of machines with diesel drive enables realization of transportation with direct supervision from shaft bottom to working. High mobility of machines driven by diesel engines and independence from stationary sources of energy such as electric power or compressed air are the other advantages $[6,11]$.

Planned increase of number of diesel drives [2] is associated with problems mainly as regards their impact on mining environment. It is the result of requirements as regards emission of toxic components of exhaust gases to the mine atmosphere [8]. Safe use of machines driven by diesel engine, especially in workings potentially threatened by methane and/or coal dust explosion hazard, requires meeting of many specific requirements, both at the stage of their designing and manufacturing as well as during their operation. All the requirements mainly refer to diesel drive considered as diesel engine with its auxiliary equipment.

\section{Legal regulations as regards operation of diesel drives in the mining industry}

Free flow of goods on the joint European market is one of the main ideas of European Union. European market is based on legal regulations included in the resolution of the Council of Europe from 1985, which is treated as a new approach to

\section{Wstęp}

Począwszy od końca lat siedemdziesiątych XX wieku w podziemiach polskich kopalń węgla kamiennego znajdują zastosowanie urządzenia transportowe z napędem spalinowym, zastępując lub uzupełniając stosowane dotąd powszechnie napędy elektryczne akumulatorowe, pneumatyczne oraz linowe. Przyczyną tego są zarówno uwarunkowania gospodarcze, jak i społeczne, które skłaniają zarządy kopalń do maksymalnego obniżenia kosztów wydobycia, zmniejszenia uciążliwości prac oraz zwiększenia ich bezpieczeństwa. Ten ostatni aspekt wynika głównie z wyeliminowania niebezpiecznych urządzeń z napędem linowym. Stosowanie urządzeń z napędami spalinowymi umożliwia realizacje transportu od podszybia do wyrobiska $\mathrm{z}$ jego bezpośrednim nadzorem. Inne zalety, to duża mobilność urządzeń napędzanych silnikami spalinowymi oraz uniezależnienie się od stacjonarnych źródeł energii, takich jak energia elektryczna lub sprężone powietrze $[6,11]$. Obecnie brak jest aktualnych danych statystycznych dotyczących liczby urządzeń górniczych wyposażonych w poszczególne systemy napędu, przy czym istnieje wyraźna tendencja wzrostowa stosowania $\mathrm{w}$ tych urządzeniach napędu silnikami spalinowymi.

Prognozowane zwiększenie liczby napędów spalinowych [2] wiąże się z problemami związanymi głównie z ich wpływem na środowisko górnicze. Jest to wynikiem wymagań bezpośrednio dotyczących emisji toksycznych składników spalin do atmosfery kopalnianej [8]. Bezpieczne stosowanie urządzeń napędzanych silnikiem spalinowym, zwłaszcza w wyrobiskach potencjalnie zagrożonych wybuchem metanu i/lub pyłu węglowego wymaga spełnienia wielu specyficznych wymagań, tak na etapie ich projektowania i wykonywania, jak również podczas ich eksploatacji. Wszystkie te wymagania w głównej mierze dotyczą napędu spalinowego 
technical harmonization and standards and which was completed in 1989 with the resolution of the Council of Europe as regards global approach to assessment of conformity [5]. Rules of new and global approach were implemented in Poland by the "Decree dated 30th August 2002 on the system for conformity assessment" [5] with later amendments. This decree belongs to so-called horizontal law that adapts EU legal acts, including directives, to the Polish law.

Basic requirements as regards diesel drives for mining industry are included in 2006/4/EC Directive, so-called New Machinery Directive (implemented by the Decree of the Minister of Economy dated 21st October 2008 [9]).

In the case of diesel drives, which are designed to be used in underground workings of hard coal mines, assessment of conformity with basic requirements included in the EU Directive No. 94/9/EC (ATEX) dated 23rd March 1994 (implemented by the Decree of the Minister of Economy dated 22nd December 2005 [10]) is also required.

According to the idea of common use of Directives, the problems that are included in the Directives are formulated in a general way to cover possibly all cases which refer to the subject of a given Directive. Detailed information as regards requirements of small group of products is included in harmonized standards.

The product is considered that it meets basic requirements if it is conform to harmonized standards. The most important standards harmonized with Machinery Directive, which refer to problems of mining diesel drives, are as follows:

- PN-EN 1679-1:2000 "Piston diesel engines - Safety Self-ignition engines",

- PN-EN 1889-2:2005 "Machines for underground mining industry - Underground self-propelled machines - Safety - Part 2: Rail locomotives".

In the case of ATEX Directive the Standard PN-EN 1834-2:2002 "Piston diesel engines - Safety requirements as regards designing and construction of engines for use in rooms threatened by explosion hazard - Part 2: Engines from group I are designed for use in underground areas threatened by methane and/or flammable dust".

We can distinguish four basic solutions of diesel systems for use in rooms threatened by explosive atmosphere, which are presented in Figure 1. They are differentiated depending on area from which air is sucked and area to which exhaust gases are emitted.

"C" configuration (Fig. 1) presents diagram of diesel engine designed for zones threatened by methane and/or flammable dust explosion hazard (PN-EN 1834-2:2002). Underground workings in hard coal mines belong to such a zone. In that configuration both air necessary for combustion process is sucked and combustion products are emitted in the area potentially threatened by explosion. Other configurations are not accepted to be used in equipment designed for operation in underground workings threatened by potentially explosive atmosphere.

In the case of diesel drives that operate in areas threatened by methane and/or flammable dust explosion hazard it is necessary to equip the driving system with a system of rozumianego, jako silnik spalinowy wraz z towarzyszącym mu osprzętem.

Zakłada się, że dalszy rozwój systemów napędu urządzeń transportowych w górnictwie będzie zmierzać do zastosowania silników spalinowych o większej mocy, w celu zwiększania prędkości transportu. W nowych rozwiązaniach ciągników są stosowane silniki o mocy powyżej $100 \mathrm{~kW}$. W związku z powyższym oraz tendencją do zwiększania udziału napędów spalinowych istnieje konieczność uzyskania maksymalnej sprawności układu napędowego oraz udoskonalenia układów odprowadzania spalin i zmniejszania ich toksyczności.

Z tych względów prognozuje się też rozwój napędów spalinowo-elektrycznych, które dadzą możliwość odzysku energii w trakcie hamowania i jej akumulację. Rozwój napędów hybrydowych dla górnictwa węglowego i ich wprowadzenie na skalę przemysłową, ze względu na koszty i doświadczenie eksploatacyjne, zależy w dużym stopniu od rozwoju tego typu układów w pojazdach samochodowych.

Jednocześnie przewiduje się wprowadzanie nowej generacji akumulatorów i silników elektrycznych, które mogą stać się konkurencyjne dla napędów spalinowych. W związku z tym należy zakładać, że w najbliższej przyszłości napędy spalinowe i elektryczne będą rozwijane zgodnie z uwarunkowaniami zrównoważonego rozwoju.

\section{Uwarunkowania dotyczące eksploatacji napędów spalinowych $\mathbf{w}$ górnictwie}

Swobodny przepływ towarów na wspólnym rynku europejskim jest jednym z głównych celów Unii Europejskiej. System funkcjonowania wspólnego rynku europejskiego opiera się na uregulowaniach prawnych ujętych w uchwale Rady WE z 1985 r., określanej jako nowe podejście do harmonizacji technicznej i norm, uzupełnionej w 1989 r. uchwałą Rady WE dotyczącą globalnego podejścia do oceny zgodności [5]. Zasady nowego i globalnego podejścia wprowadziła w Polsce „Ustawa z dnia 30 sierpnia 2002 r. o systemie oceny zgodności" [5], wraz z późniejszymi zmianami. Ustawa ta zaliczana jest do tzw. ustaw horyzontalnych transponujących do prawodawstwa krajowego akty prawne UE w tym dyrektywy.

Wymagania zasadnicze dotyczące napędów spalinowych dla górnictwa zawarte są w Dyrektywie 2006/4/WE tzw. Nowej Dyrektywie Maszynowej (wdrożonej Rozporządzeniem Ministra Gospodarki z dnia 21.10.2008 r. [9]).

W przypadku napędów spalinowych przeznaczonych do zastosowania w podziemnych wyrobiskach węgla kamiennego wymagana jest także ocena zgodności z wymaganiami zasadniczymi zapisanymi w Dyrektywie Unii Europejskiej nr 94/9/WE - ATEX z dnia 23 marca 1994 (wdrożonej rozporządzeniem Ministra Gospodarki z dnia 22 grudnia 2005 r. [10]).

Zgodnie z przyjętą koncepcją uwarunkowaną powszechnością zastosowania Dyrektyw, ujmowane w nich zagadnienia są formułowane w sposób ogólny, tak, aby mogły objąć możliwie wszystkie przypadki dotyczące ich przedmiotu. Informacje szczegółowe dotyczące wymagań zawężonej gru- 
automated stopping (switching off) of diesel engine when permissible value of rotary speed is exceeded, as well as automated stopping or self-protection of engine should occur in the case of the following hazards:

- exceeding of permissible temperature of liquid in a cooling system of diesel engine,

- insufficient pressure of lubricating oil,

- too small amount of liquid in a cooling system,

- exceeding of permissible temperature of exhaust gases,

- exceeding of permissible temperature of engine oil,

- exceeding of permissible temperature of hydraulic oil.

Additionally, in the case of occurrence of one of the mentioned above hazards the control system should signalize the emergency state.

Fuel cut-off from the system supplying the engine should be the method for automated stopping of engine both normal and emergency and moreover, each engine should be equipped with valve cutting off air supply.

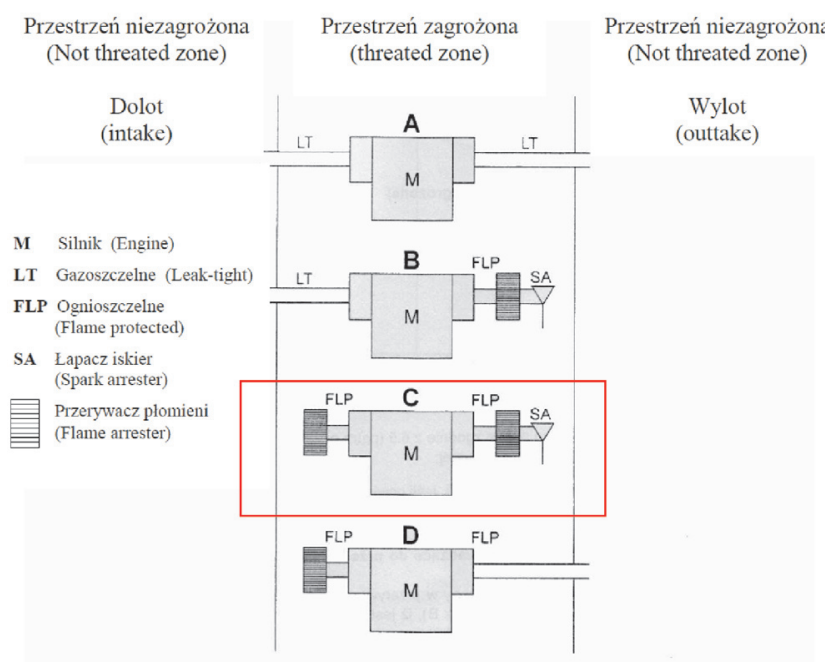

Fig. 1. Accepted solutions of installation of diesel engine Rys. 1. Dopuszczalne rozwiazania zabudowy silnika spalinowego

Requirements as regards permissible temperature of external surface of components of the whole driving system is one of the most important conditions, which are necessary to be met when diesel engines are used in mining diesel drives operated in coal mines. According to the requirements that are in force, temperature of external surface of all engine components and temperature of exhaust gases emitted to the atmosphere after flame arrestor cannot exceed $150^{\circ} \mathrm{C}$. It refers to operational conditions of engine under full load.

Permissible values of emission of toxic substances in exhaust gases as regards mining diesel drives are included in PN-EN 1679-1:2000 Standard. This refers to diesel engines of power from 37 to $560 \mathrm{~kW}$. For engines of power lower than 37 $\mathrm{kW}$ limiting values were not given because hazards associated with those engines are assumed to be not essential.

According to 97/68/EC Directive (Diesel Engine Directive) mining diesel drives can be qualified as "non-road mobile machines". Driving units, which are mentioned in py wyrobów zapisane są w normach zharmonizowanych.

Zakłada się, że wyrób spełnia wymagania zasadnicze, jeżeli jest zgodny z normami zharmonizowanymi. Najważniejsze $z$ nich, dotyczące problematyki górniczych napędów spalinowych, w przypadku norm zharmonizowanych z Dyrektywą Maszynową to między innymi:

- PN-EN 1679-1:2000 „Silniki spalinowe tłokowe Bezpieczeństwo - Silniki o zapłonie samoczynnym",

- PN-EN 1889-2:2005 „Maszyny dla górnictwa podziemnego - Podziemne maszyny samobieżne - Bezpieczeństwo - Część 2: Lokomotywy szynowe".

W przypadku Dyrektywy ATEX najważniejszą normą zharmonizowaną dotyczącą napędów spalinowych jest norma PN-EN 1834-2:2002 ,Silniki spalinowe tłokowe - Wymagania bezpieczeństwa dotyczące projektowania i budowy silników przeznaczonych do stosowania w przestrzeniach zagrożonych wybuchem - Część 2: Silniki grupy I przeznaczone do stosowania w pracach podziemnych zagrożonych występowaniem metanu i/ lub palnego pyłu".

Do zastosowania strefach zagrożonych atmosferą wybuchową możemy wyróżnić cztery podstawowe rozwiązania układów spalinowych, które zilustrowano na rys. 1. Rozróżnia się je ze względu na przestrzeń, z której zasysane jest powietrze oraz przestrzeń, do której emitowane są spaliny.

Konfiguracja „C” (rys. 1) przedstawia schemat napędu spalinowego przeznaczonego do stref zagrożonych wybuchem metanu i/lub pyły palnego (PN-EN 1834-2:2002). Do takich stref zaliczamy podziemne wyrobiska w kopalniach węgla kamiennego. W tej konfiguracji zarówno powietrze potrzebne do procesu spalania, jak i produkty spalania zasysane i emitowane są w przestrzeni potencjalnie zagrożonej wybuchem. Pozostałe konfiguracje nie są dopuszczone do eksploatacji w urządzeniach przeznaczonych do wyrobisk podziemnych zagrożonych atmosferą potencjalnie wybuchową.

Dla napędów spalinowych eksploatowanych w przestrzeniach zagrożonych wybuchem metanu i/lub pyłu palnego, koniecznym jest wyposażenie układu napędowego w system samoczynnego (automatycznego) zatrzymania (wyłączenia) silnika spalinowego przy przekroczeniu nadmiernej prędkości obrotowej, a także samoczynne zatrzymanie lub samoczynne zabezpieczenie silnika w przypadku następujących stanów zagrożenia:

- przekroczenie dopuszczalnej temperatury cieczy w układzie chłodzenia silnika spalinowego,

- niedostateczna wartości ciśnienia oleju smarującego,

- zbyt mała ilość cieczy w układzie chłodzenia,

- przekroczenie dopuszczalnej temperatury spalin,

- przekroczenie dopuszczalnej temperatury oleju silnikowego,

- przekroczenie dopuszczalnej temperatury oleju hydraulicznego.

Dodatkowo, w przypadku wystąpienia jednego z wymienionych zagrożeń, układ kontroli powinien sygnalizować to w postaci stanu alarmowego. 
that Directive and which refer to the same power range (as for ranges presented in Table 1) have to meet requirements as regards values of emission presented in Table 2 .

Limiting values of toxic substances, which are included in Table 1, meet the requirements as regards emission included in "Stage 1" of Diesel Engine Directive. It should be emphasized that, according to $\S 13.2$ of above mentioned Directive, homologation certificates are not issued for such units after 1998. Comparing two above legal acts it can be said that regulations associated with commercialization of mining diesel drives treats the problem of emission of toxic substances quite liberally. For example, higher emission

Table 1. Permissible values of emission of toxic substances acc. to PN-EN 1679-1:2000 Standard [3]

Tabela 1. Dopuszczalne wartości emisji substancji toksycznych wg PN-EN 1679-1:2000 [3]

\begin{tabular}{|c|c|c|c|c|}
\hline $\begin{array}{c}\text { Power/moc } \\
\mathrm{P}\end{array}$ & $\begin{array}{c}\text { Carbon monoxide/ } \\
\text { tlenek węgla } \mathrm{CO}\end{array}$ & $\begin{array}{c}\text { Hydrocarbons/ } \\
\text { węglowodory } \mathrm{HC}\end{array}$ & $\begin{array}{c}\text { Nitrogen oxides/ } \\
\text { tlenki azotu } \mathrm{NO}_{\mathrm{x}}\end{array}$ & $\begin{array}{c}\text { Solid particles/ } \\
\text { czaqstki state } \mathrm{PT}\end{array}$ \\
\hline$[\mathrm{kW}]$ & {$[\mathrm{g} / \mathrm{kWh}]$} & {$[\mathrm{g} / \mathrm{kWh}]$} & {$[\mathrm{g} / \mathrm{kWh}]$} & {$[\mathrm{g} / \mathrm{kWh}]$} \\
\hline $37 \leq \mathrm{P}<75$ & 6.5 & 1.3 & 9.2 & 0.85 \\
\hline $75 \leq \mathrm{P}<130$ & 5.0 & 1.3 & 9.2 & 0.70 \\
\hline $130 \leq \mathrm{P}<560$ & 5.0 & 1.3 & 9.2 & 0.54 \\
\hline
\end{tabular}

of toxic substances from drives operated in underground workings of confined space was accepted unlike for the drives operated in open space. Such procedure seems to be unjustified due to its impact on health of members of mining teams.

Legal entries that refer to ventilation of underground workings, which are included in the Decree of the Minister of Economy dated 28th June 2002 as regards work safety, transportation and specialistic fire-fighting protection in underground mining plants, are of great importance as regards quality of exhaust gases [8].

According to $\S 187$ of the Decree [8] all available workings and rooms should be ventilated in such way that concentration of oxygen in air is not lower than 19\% (by volume) and the highest permissible concentration of other, gaseous components does not exceed values presented in Table 3.

Table 2. Permissible values of emission of toxic substances acc. to 97/68/EC Directive[4]

Tabela 2. Dopuszczalne wartości emisji substancji toksycznych wg Dyrektywy 97/68/WE [4]

\begin{tabular}{|c|c|c|c|c|c|}
\hline $\begin{array}{c}\text { Power } / m o c \\
\mathrm{P}\end{array}$ & $\begin{array}{c}\text { Date/data } \\
\text { wprowadzenia }\end{array}$ & $\begin{array}{c}\text { Carbon monoxide/ } \\
\text { tlenek węgla } \mathrm{CO}\end{array}$ & $\begin{array}{c}\text { Hydrocarbons/ } \\
\text { węglowodory HC }\end{array}$ & $\begin{array}{l}\text { Nitrogen oxides/ } \\
\text { tlenki azotu } \mathrm{NO}_{\mathrm{x}}\end{array}$ & $\begin{array}{l}\text { Solid particles/ } \\
\text { cząstki stałe } \mathrm{PT}\end{array}$ \\
\hline$[\mathrm{kW}]$ & & [g/kWh] & [g/kWh] & [g/kWh] & {$[\mathrm{g} / \mathrm{kWh}]$} \\
\hline \multicolumn{6}{|c|}{ Stage $3 \mathrm{~A}$} \\
\hline $19 \div 37$ & 01.2007 & 5.5 & $\mathrm{NO}_{x}+\mathrm{HC}-7.5$ & 0.6 & \\
\hline $37 \div 75$ & 01.2008 & 5.0 & $\mathrm{NO}_{\mathrm{x}}+\mathrm{HC}-4.7$ & 0.4 & \\
\hline $75 \div 130$ & 01.2007 & 5.0 & $\mathrm{NO}_{\mathrm{x}}+\mathrm{HC}-4.0$ & 0.3 & \\
\hline $130 \div 560$ & 01.2006 & 3.5 & $\mathrm{NO}_{\mathrm{x}}+\mathrm{HC}-4.0$ & 0.2 & \\
\hline \multicolumn{6}{|c|}{ Stage 3B } \\
\hline $37 \div 56$ & 01.2013 & 5.0 & $\mathrm{NO}_{\mathrm{x}}+\mathrm{HC}-4.7$ & 0.025 & \\
\hline $56 \div 75$ & 01.2012 & 5.0 & 0.19 & 3.3 & 0.025 \\
\hline $75 \div 130$ & 01.2012 & 5.0 & 0.19 & 3.3 & 0.025 \\
\hline $130 \div 560$ & 01.2011 & 3.5 & 0.19 & 2.0 & 0.025 \\
\hline
\end{tabular}


As regards emission of harmful compounds by diesel engine the above mentioned Decree directly determines maximal amount of carbon oxide in exhaust gases emitted to mine atmosphere at the level of $500 \mathrm{ppm}$. Summarizing formaland-legal requirements as regards quality of exhaust gases it can be said that meeting the requirements of Diesel Engine Directive as regards permissible emission also guarantees meeting the requirements of PN-EN 1679-1:2000 Standard. However, meeting the basic requirements as regards quality of exhaust gases is not a sufficient condition enabling safe min-

W kwestii jakości spalin istotne znaczenie mają zapisy prawne dotyczące wentylacji wyrobisk podziemnych, zawarte w Rozporządzeniu Ministra Gospodarki z dnia 28 czerwca 2002 w sprawie bezpieczeństwa i higieny pracy, prowadzenia ruchu oraz specjalistycznego zabezpieczenia przeciwpożarowego w podziemnych zakładach górniczych [8].

Zgodnie z $\$ 187$ Wszystkie dostępne wyrobiska i pomieszczenia należy przewietrzać w taki sposób, aby stężenie tlenu w powietrzu nie było mniejsze niż 19\% (objętościowo), a najwyższe dopuszczalne stężenie innych, gazowych składników nie przekraczało wartości przedstawionych w tabeli 3 .

Niniejsze rozporządzenie, w

Table 3. Permissible concentration of gases in mine working [8]

Tabela 3. Dopuszczalne stężenie gazów w wyrobisku górniczym [8]

\begin{tabular}{|c|c|c|}
\hline Type of gas/rodzaj gazu & $\begin{array}{c}\mathrm{NDS} / \mathrm{mg} / \mathrm{m}^{3} \\
\text { (\% volume/objętościowo i\%) }\end{array}$ & $\begin{array}{c}\mathrm{NDSCh} / \mathrm{mg} / \mathrm{m}^{3} \\
(\% \text { volume/objętościowo i \%) }\end{array}$ \\
\hline Carbon dioxide/dwutlenek węgla & $-(1.0)$ & $-(1.0)$ \\
\hline Carbon monoxide/tlenek węgla & $30(0.0026)$ & $180(0.015)$ \\
\hline Nitrogen oxide/tlenek azotu & $5(0.00026)$ & $10(0.00052)$ \\
\hline Sulphur dioxide/dwutlenek siarki & $2(0.000075)$ & $5(0.0019)$ \\
\hline Hydrogen sulfide/siarkowodór & $10(0.0007)$ & $20(0.0014)$ \\
\hline
\end{tabular}
kwestii emisji szkodliwych związków przez silnik spalinowy, bezpośrednio określa maksymalna ilość tlenku węgla w spalinach emitowanych do atmosfery kopalnianej, którego stężenie nie może przekroczyć 500 ppm. Podsumowując wymagania formalno-prawne dotyczące jakości spalin można

ing in mine workings, because safe use of such drive cannot result in exceeding of limiting values of toxic substances in mine atmosphere, which are presented in Table 3, as well as of permissible emission of carbon oxide.

\section{Diesel drive for the coal mining industry developed by KOMAG}

BF4M1013 engine made by Deutz and sold under VolvoPenta trade mark as the engine used for watercrafts has been used in the state-of-the-art solutions of mine diesel drives, developed by KOMAG and designed for operation in the workings threatened by methane and/or coal dust explosion hazard (Fig. 2).

This is an engine designed for sea watercrafts that was adapted for application in mining equipment. Fire is one of main possible hazards that can occur in watercrafts. But fire is also the hazard that is one of most dangerous hazards stwierdzić, że spełnienie wymagań Dyrektywy Spalinowej w zakresie dopuszczalnej emisji gwarantuje także spełnienie wymogów normy PN-EN 1679-1:2000. Spełnienie wymagań zasadniczych dotyczących jakości spalin nie jest jednakże warunkiem wystarczającym, umożliwiającym bezpieczną eksploatację w wyrobiskach górniczych, gdyż bezpieczne użytkowanie takiego napędu nie może powodować przekroczenia granicznych wartości stężenia substancji toksycznych w atmosferze kopalnianej przedstawionych w tabeli 3, jak również dopuszczalnego stężenia tlenku węgla.

\section{Rozwiązanie napędu spalinowego KOMAG-u dla górnictwa węgla kamiennego}

W najnowszych konstrukcjach górniczych napędów spalinowych przeznaczonych do pracy w wyrobiskach zagrożonych wybuchem metanu i/lub pyłu węglowego opracowanych w KOMAG-u wykorzystuje się, silnik typu
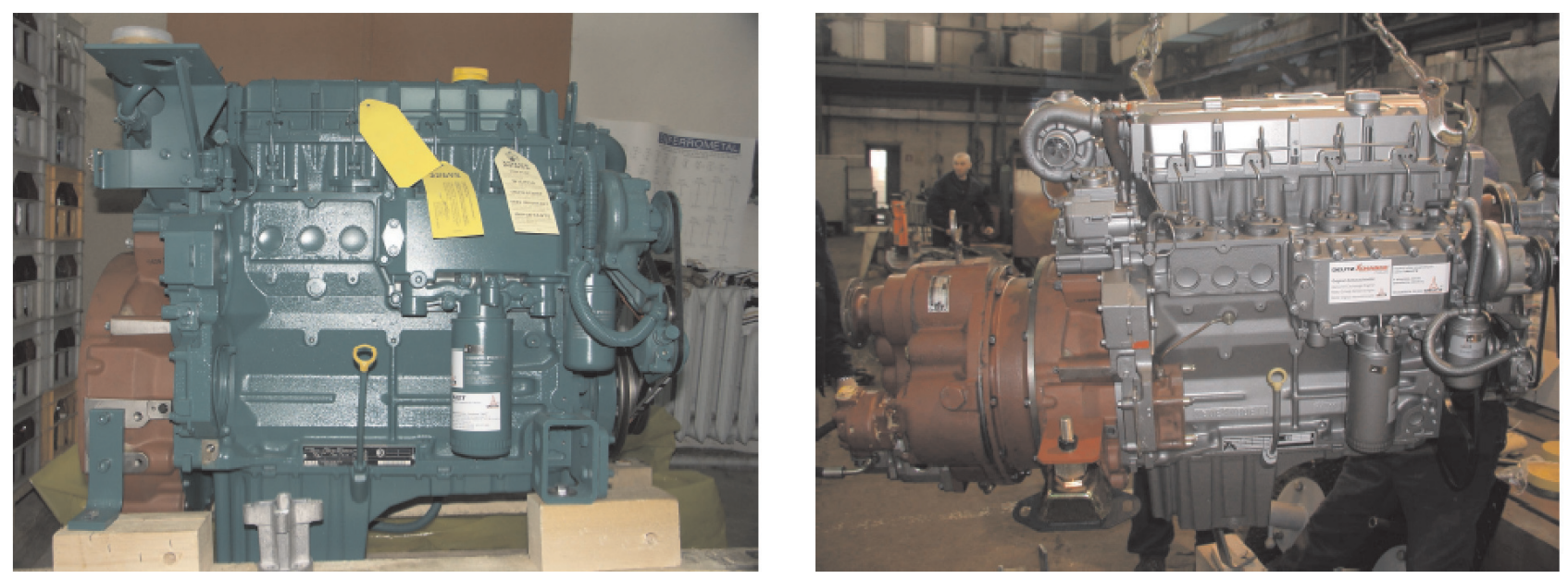

Fig. 2. ZS (Deutz BF4M1013) diesel engine for mining machines with liquid cooled outlet collector and turbocharger Rys. 2. Silnik spalinowy ZS (Deutz BF4M1013) do maszyn górniczych z chłodzonym cieczą kolektorem wylotowym i turbosprężarka 
in the mining industry. So the engine is equipped with the protective structures that prevent engine's external surfaces against excessive temperature. On the basis of the abovementioned engine design the mine diesel drive for underground transportation machines, operating in potentially explosive atmosphere, has been developed (Fig .3).

The listed components from flame arrester in the inlet system to flame arrester in the exhaust system make so-

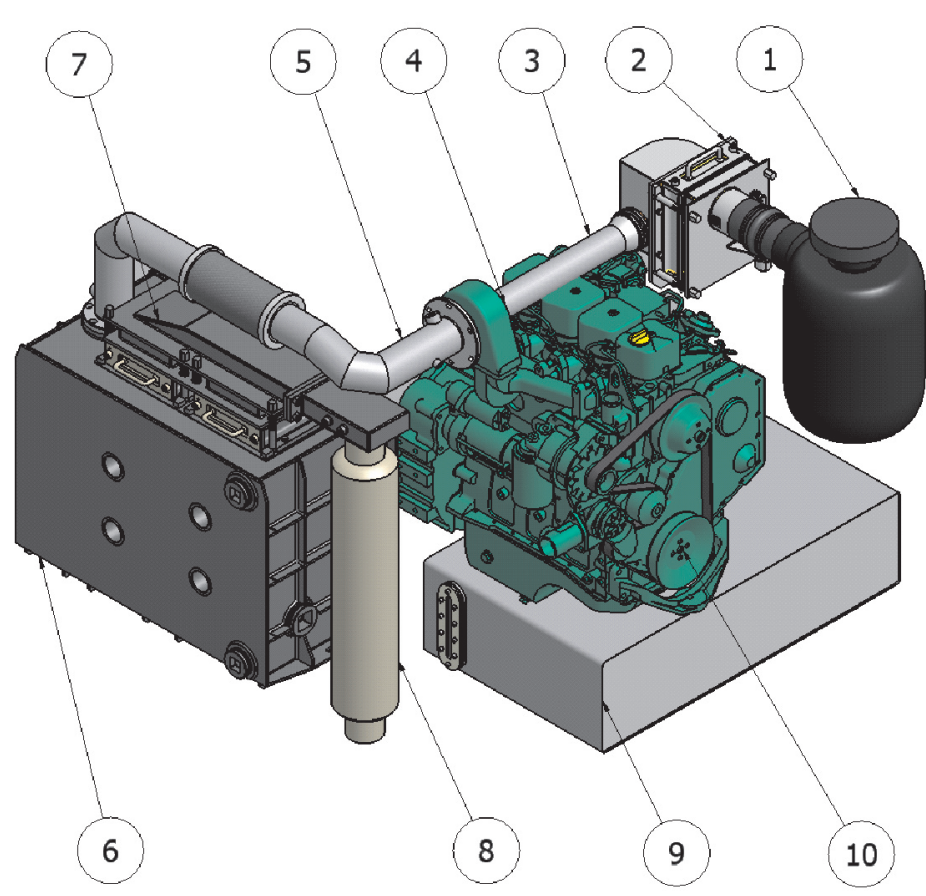

Fig. 3. Model of diesel drive developed by KOMAG. 1 - air filter, 2 - flame arrester in inlet system, 3 - inlet hose, 4 - turbocharger, 5 - exhaust gases outlet hose, 6 - water exhaust gases washer, 7 - flame arrester in exhaust system with exhaust manifold, 8 spark arrester, 9 - fuel tank, 10 - ZS diesel engine

Rys. 3. Model górniczego napędu spalinowego opracowanego w KOMAG-u: 1 - filtr powietrza, 2 - przerywacz płomieni układu dolotowego, 3 - przewód dolotowy, 4 turbosprężarka, 5-przewód wylotu spalin, 6-wodna płuczka spalin, 7 -przerywacz płomieni układu wylotowego z kolektorem zbiorczym, 8-iskrochron, 9 - zbiornik paliwa, 10 - silnik spalinowy ZS

called inlet-outlet flameproof system (PN-EN 1834-2:2002). Flame arrester (item 2) is the most important component of the inlet system. It protects against flames spread from the flameproof part to the surrounding atmosphere. Flame arrester has a form of cassette with plates with a slot between them. Slot width "S" and its length "L" are important parameters of flame arrester. Flame arrester design is shown in Fig. 4.

Exhaust gases generated in fuel burning process are taken off through the exhaust system in which exhaust gases outlet hose is its first component (item 5). The hose has socalled water coat that protects external surface against exceeding its temperature above $150^{\circ} \mathrm{C}$, and initially reduces exhaust gases tempera-

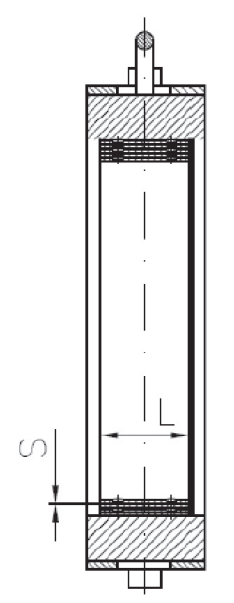

BF4M1013 firmy Deutz, oferowany pod marką Volvo-Penta jako silnik do jednostek pływających (rys. 2).

Jest to silnik przeznaczony do morskich jednostek pływających, który został przystosowany do zastosowań w urządzeniach górniczych. Jednym z podstawowych zagrożeń możliwych do wystąpienia na jednostkach pływających jest zagrożenie pożarem. To zagrożenie zalicza się również do jednych z najniebezpieczniejszych w górnictwie. W związku $\mathrm{z}$ tym silnik ten jest wyposażony w odpowiednie konstrukcje zabezpieczające zewnętrzne powierzchnie silnika przed osiągnięciem nadmiernej temperatury. Na bazie w/w silnika opracowano górniczy napęd spalinowy przeznaczony do dołowych urządzeń transportowych eksploatowanych $\mathrm{w}$ atmosferze potencjalnie wybuchowej (rys. 3).

Wymienione elementy, począwszy od dolotowego przerywacza płomieni, do wylotowego przerywacza płomieni, stanowią tzw. dolotowowylotowy układ ognioszczelny (PN-EN 18342:2002). Najbardziej istotnym elementem układu dolotowego jest kasetowy przerywacz płomieni (poz. 2), którego budowę przerywacza pokazano na rysunku 4. Jego zadaniem jest zabezpieczenie przed przedostaniem się płomieni z części ognioszczelnej do otaczającej atmosfery i z tego względu ważnym parametry przerywacza są: szerokość szczeliny „,S” oraz jej długości „L”.

Spaliny powstałe $\mathrm{w}$ procesie spalania są odprowadzane poprzez układ wylotowy, którego pierwszym elementem jest przewód wylotowy spalin (poz. 5), wyposażony w tzw. płaszcz wodny. Zabezpiecza to powierzchnię zewnętrzną przed przekroczeniem wartości temperatury powyżej $150^{\circ} \mathrm{C}$, oraz obniża wstępnie temperaturę samych spalin. Podstawowym zespołem służącym do obniżenia temperatury spalin jest płuczka wodna (poz. 6), za którą zabudowany jest szczelinowy przerywacz płomieni układu

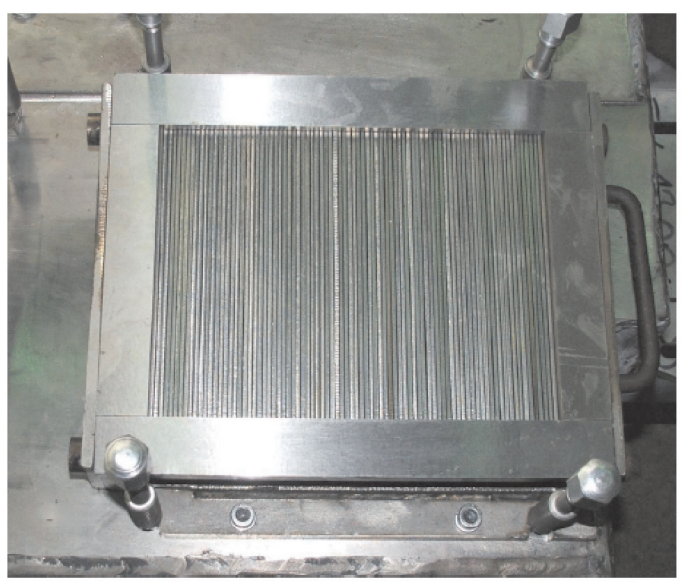

Fig. 4. Design of cassette flame arrester

Rys. 4. Budowa przerywacza kasetowego 
ture. Water washer (item 6) is the main unit that reduces temperature of exhaust gases. After the washer there is a flame arrester of exhaust system (item 7). Its design and function is the same as of flame arrester in the inlet system. After the flame arrester the flameproof part of exhaust system ends. Dry spark arrester (item 8) is the end component. Water washer also plays the role of spark arrester and it is so-called the wet spark arrester. To meet requirements regarding maximal temperature of engine surface included in the regulations, the engine has been equipped with the cooling system to which cooling the exhaust collector and turbocharger was included.

The engine its connections and auxiliary equipment together with flame arresters, spark arrester and hoses undergoes the EC type test according to PN-EN 1834-2 standard according to flameproof shield test and according to flame arresting test.

Flameproof shield test includes:

- determination of maximal explosion pressure. Generation of explosion that can be found inside the flameproof shield (e.g. in inlet or exhaust system) and its measurement is the purpose of the test,

- pressure test. Applying of changing pressure, found in the test, and confirmation that in such conditions the shields does not lose its properties, is the purpose of the test.

- "not spreading" tests. Generation of explosion that can be found in inlet or exhaust system and confirmation that in such conditions the explosion is arrested in the flameproof shield and will not spread to the surrounding atmosphere, is the purpose of the test.

To carry out flameproof shield test, the shield is equipped from the inlet flame arrester (together with that arrester) to the exhaust flame arrester with so-called plugging plate that replaces cylinder block and it is connected to the chamber simulating cylinder volume. The plate design should enable fixation of a chamber simulating cylinder volume with ignition source at each opening (inlet openings and outlet opening of combustion chamber. Testing gas used during testing is a mixture of methane/hydrogen with air. Additionally for the pressure test and not spreading test the testing object is placed in a testing flameproof chamber that in the case of not spreading tests is also filled with the testing gas.

It should be stated that engine components due to the necessity of meeting ATEX Directive requirements are expanded, what causes significant weight increase and increase of dimensions of a drive unit. Besides, operation of the engine requires inspections and servicing as regards many connections in the exhaust gases take off system as well as requires frequent refill of water in the exhaust gases washer.

\section{Exemplary application of transportation ma- chines with diesel drive used in the hard coal mining industry}

In the result of KOMAG collaboration with the following companies: FMG PIOMA S.A., RFM RYFAMA S.A., ENERGO-MECHANIK Sp. z o.o. and VACAT Sp. $\mathrm{z}$ o.o. many solutions of transportation machines with wylotowego (poz. 7). Za przerywaczem kończy się część ognioszczelna układu wylotowego. Końcowym elementem jest suchy łapacz iskier (iskrochron) (poz. 8).

W celu spełnienia wymagań dotyczących maksymalnej temperatury powierzchni zewnętrznych silnika, został on wyposażony w system chłodzenia kolektora wylotowego i turbosprężarki, poprzez włączenie tych elementów do obiegu cieczy chłodzącej silnik.

Silnik, jego połączenia i urządzenia pomocnicze wraz z przerywaczami płomieni, łapaczem iskier i przewodami poddaje się próbie typu osłony ognioszczelnej i próbie łapacza iskier zgodnie z PN-EN 1834-2.

Próba osłony ognioszczelnej, obejmuje:

- określenie maksymalnego ciśnienia wybuchu. Celem tej próby jest wywołane i pomiar wybuchu, jakie można się spodziewać w osłonie ognioszczelnej (np. w układzie dolotowym lub wylotowym),

- próbę ciśnieniową. Celem tej próby jest poddanie osłony działaniu ciśnienia stwierdzonego w czasie badań i wykazanie, że w takich warunkach osłona ognioszczelna zachowuje swoje własności.

- próbę „nieprzenoszenia”. Celem tej próby jest przeprowadzenie wybuchu, jaki może się zdarzyć w układzie dolotowym lub wylotowym i wykazanie, że w tych warunkach wybuch zostaje powstrzymany w osłonie ognioszczelnej i nie przenosi się do otaczającej atmosfery.

W celu przeprowadzenia próby danego typu osłony ognioszczelnej, osłonę wyposaża się w tzw. płytę zaślepiającą obejmującą obszar od przerywacza płomieni na dolocie, łącznie z tym przerywaczem, do przerywacza płomieni na wylocie, która zastępuje blok cylindrowy i połączona jest z komorą symulującą objętość cylindra. Konstrukcja płyty powinna umożliwiać zamocowanie komory symulującej objętość cylindra wraz z źródłem zapłonu przy każdym otworze (otwory dolotowe i wylotowe komory spalania). Gaz badawczy używany w czasie prób to mieszanina metan/wodór z powietrzem. Dodatkowo dla próby określenia maksymalnego ciśnienia i próby nieprzenoszenia, obiekt badawczy umieszcza się w ognioszczelnej komorze badawczej, która w przypadku próby nieprzenoszenia jest również wypełniona gazem badawczym.

Należy podkreślić, że elementy wyposażenia silnika, wynikające z konieczności spełnienia wymagań Dyrektywy ATEX są rozbudowane i powodują znaczące zwiększenie masy i wymiarów zespołu napędowego. Jego eksploatacja wymaga ponadto częstych czynności kontrolnych i serwisowych, związanych ze sprawdzaniem szczelności wielu połączeń systemu wyprowadzania spalin, jak również częstego uzupełniania cieczy w wodnej płuczce spalin.

\section{Przykładowe aplikacje urządzeń transportowych $\mathrm{z}$ napędem spalinowym dla górnictwa węgla kamiennego}

W ramach prowadzonej współpracy KOMAG-u z firmami: FMG PIOMA S.A., RFM RYFAMA S.A., ENERGOMECHANIK Sp. z o.o. oraz firmą VACAT Sp. z o.o. powstało szereg rozwiązań urządzeń transportowych zasilanych 
diesel drives used in the hard coal mining industry were developed:

- PIOMA CS 80 suspended diesel locomotive,

- PIOMA LDS 80 underground diesel locomotive,

- PIOMA-VACAT floor-mounted diesel railway,

- SKZ-81 rack railway,

- Lds-100K-EMA underground diesel locomotive.

\subsection{PIOMA CS 80 suspended diesel locomotive}

In the result of collaboration between PIOMA S.A. Mining Machines Factory in Piotrkow Trybunalski and KOMAG Institute of Mining Technology the factory offers suspended monorails with diesel engine for the coal mining industry.

The following locomotives are the extension of the previous production of PIOMA CS 80 locomotives (Fig. 5):

- PIOMA CSP 3 with three driving cars,

- PIOMA CSP 4 with four driving cars,

- PIOMA CSP 5 with five driving cars.

The diesel-and-hydraulic drive developed in the abovementioned solution was adapted to next solutions developed in KOMAG (in collaboration with FMG PIOMA S.A. and VACAT Sp. z o.o.) [1].

\subsection{PIOMA LSD 80 underground diesel locomotive}
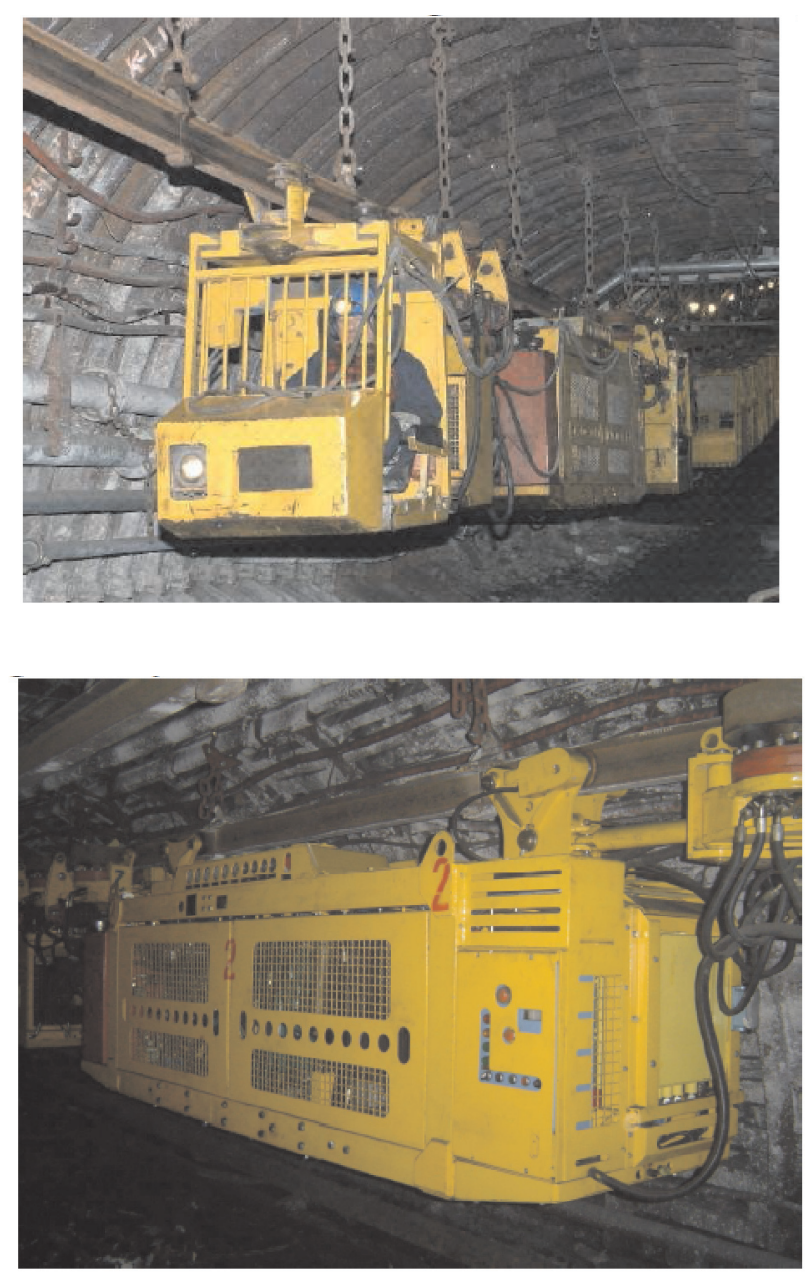

Fig. 5. Diesel suspended monorail with PIOMA CS 80 locomotive [1] Rys. 5. Kolej podwieszana spalinowa z ciagnikiem PIOMA CS 80 [1] silnikami spalinowymi stosowanych w górnictwie.

- Podwieszony ciągnik spalinowy - PIOMA CS 80,

- Lokomotywa dołowa spalinowa - PIOMA LDS 80,

- Spalinowa kolej spągowa - PIOMA-VACAT,

- Szynowa kolej podziemna - SKZ-81,

- Lokomotywa dołowa spalinowa - Lds-100K-EMA.

Wymienione zastosowania dotyczą maszyn pracujących w górnictwie węglowym. Należy podkreślić, że ze względu na charakter zakładów górniczych węgla kamiennego oraz rud miedzi napędy spalinowe dla tych kopalń różnią się w zasadniczy sposób. Różnice te wynikają z charakteru geologicznego wyrobiska. W kopalniach węgla kamiennego występuje zagrożenie wybuchem metanu oraz pyłu węglowego. Zagrożenia te nie występują kopalniach rud miedzi. W związku z tym napędy stosowane w kopalniach węgla kamiennego muszą posiadać budowę umożliwiającą spełnienie wymagań, stawianych urządzeniom pracującym w atmosferze potencjalnie wybuchowej (dyrektywa ATEX). Wymagania te powodują miedzy innymi, że w napędach dla kopalń węgla kamiennego nie stosuje się w układach wylotowych reaktorów katalitycznych, które z kolei stają się powszechne w napędach stosowanych w kopalniach rud miedzi. Podobna sytuacja dotyczy również innych elementów układów spalinowych, między innymi chłodnicy powietrza w układzie dolotowym. W wielu kopalniach rud miedzi powszechnie stosowane są silniki pochodzące ze standardowych maszyn budowlanych. Ponadto ze względu na przekrój wyrobiska oraz stabilność spągu w kopalniach rud miedzi stosuje się w urządzenia spalinowe na nadwoziu oponowym, których nie spotyka się w kopalniach węgla kamiennego.

\subsection{Podwieszony ciągnik spalinowy PIOMA CS 80}

W wyniku rozpoczętej w 1994 r. współpracy Fabryki Maszyn Górniczych PIOMA S.A. w Piotrkowie Trybunalskim z Instytutem Techniki Górniczej KOMAG fabryka ta może aktualnie oferować górnictwu węglowemu kolejki podwieszane z napędami spalinowymi.

Rozwinięciem produkcji dotychczasowych ciągników PIOMA CS 80 (rys. 5) są ciągniki oznaczone symbolami:

- PIOMA CSP 3 z trzema wózkami napędowymi,

- PIOMA CSP 4 z czterema wózkami napędowymi,

- PIOMA CSP 5 z pięcioma wózkami napędowymi.

Powstały w w/w rozwiązaniu napęd spalinowo-hydrauliczny został zaadaptowany do kolejnych rozwiązań powstałych w KOMAG-u (przy współpracy z FMG PIOMA S.A. i firmą VACAT Sp. z o.o.) [1].

\subsection{Lokomotywa dołowa spalinowa PIOMA LSD 80}

W wyniku współpracy KOMAG-u z FMG PIOMA S.A. powstała lokomotywa PIOMA LDS 80. Lokomotywa ta charakteryzują się hydrauliczną transmisją momentu obrotowego silnika spalinowego na koła jezdne. Przy masie własnej 15 t możliwe jest ciągnięcie składów pociągowych o masie przekraczającej $150 \mathrm{t}$.

Lokomotywa zbudowana jest z trzech modułów połączonych ze sobą, umożliwiających wzajemne przemieszczanie względem osi przegubów. Moduły lokomotywy to:

- wózek napędowy, w skład którego wchodzą rama, 
In the result of collaboration between KOMAG and FMG PIOMA S.A. PIOMA LDS 80 locomotive was developed. The locomotive is characterized by a hydraulic transmission of diesel engine torque to the wheels. At its own weight $15 \mathrm{t}$ it is possible to pull trains of weight exceeding $150 \mathrm{t}$.

The locomotive is made of three modules connected with each other, what enables their reciprocal movement against joints axes. Locomotive modules are as follows:

- driving car, consisted of a frame, gears together with engines and hydraulic brakes and wheels,

- two operator cabins with fixed buffers, each cabin connected with the driving car by bolts,

- engine department with diesel and hydraulic pack, adapted from PIOMA CS 80 suspended monorail, fixed in slides connecting driving units.

Hydrostatic transmission that also plays a role of maneuvering brake was used in the drive. Hydraulic disk brakes play a role of stopping brake. The brakes act on driving wheels through a gear transmission. They start up after moving the operation lever to " 0 " position or automatically after exceeding speed limit $4.8 \mathrm{~m} / \mathrm{s}$ [1].

Design of PIOMA LDS 80 locomotive has the following advantages:

- despite its length $8.5 \mathrm{~m}$, it much better overcomes bends than one-solid locomotives (has no tendency for derailing),

- the cabins which turn themselves together with modules significantly reduce exceeding the track outline on bends, reducing the hazard to people that can stay in the range of locomotive moving line,

- locomotive pulling force transmitted to carriages by couplings is distributed almost along the line of track symmetry axis, what in the case of braking and on bends, prevents against pushing the locomotive out of the track, - even distribution of locomotive mass on all wheels improves braking efficiency of the locomotive.

The locomotive has been applied in the LW Bogdanka S. A Colliery.

\subsection{PIOMA VACAT floor-mounted diesel railway}

PIOMA VACAT floor-mounted diesel railway is the result of collaboration between KOMAG and FMG PIOMA S.A. (Fig. 7). The system for drive transfer is the characteristic feature of PIOMA-VACAT railway. Depending on requirements and condition in the workings we can use frictional or rack coupling of wheels with a drive bar between rails.

Subassemblies of PIOMA CS 80 locomotive were used to construct floor-mounted railway locomotive, installed on four drive modules. Each module has the driving system consisting of two hydraulic engines that drive friction and tooth wheels as well as it has a jaw brake system that uses frictional bar of rails.

Due to application of few driving modules the total pulling force of locomotive is transferred to more than two track segments what significantly reduces load of the track especially its bolting components and driving bar. Also the force from brakes is distributed so there is no risk of tearing off the track segment from bolted place at emergency
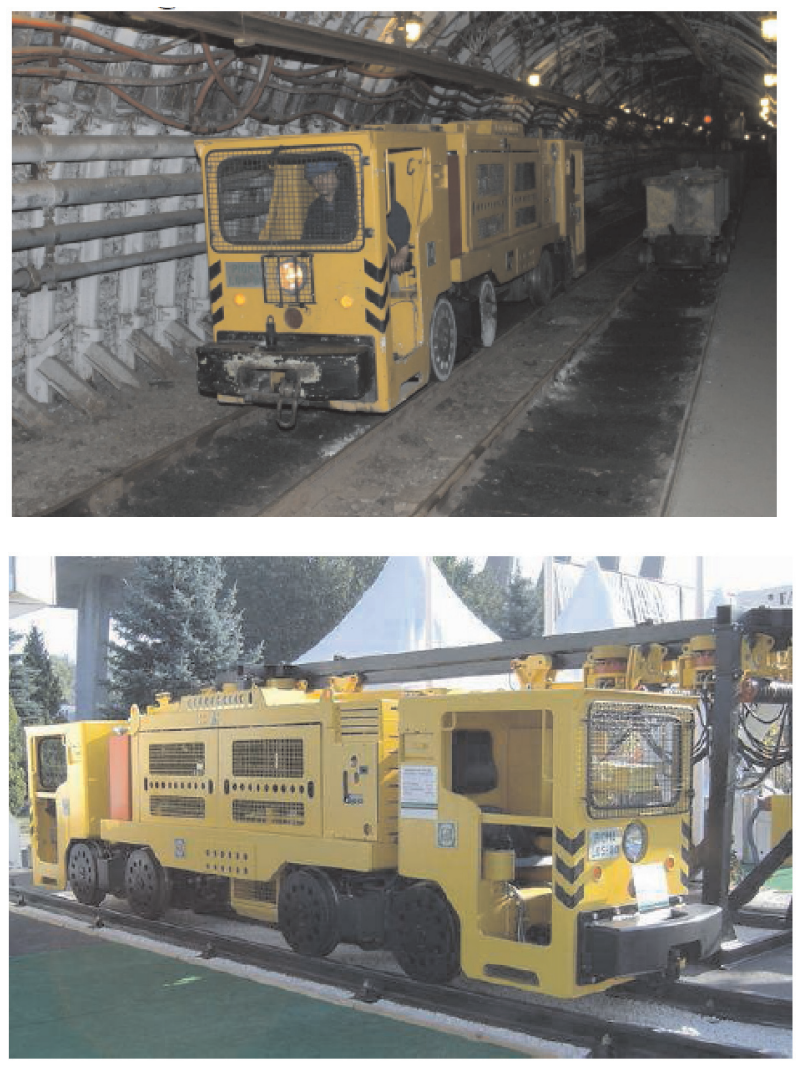

Fig. 6. PIOMA LDS 80 underground diesel locomotive [1]

Rys. 6. Lokomotywa dołowa spalinowa PIOMA LDS 80 [1]

przekładnie wraz z silnikami i hamulcami hydraulicznymi oraz kołami jezdnymi,

- dwie kabiny maszynisty z utwierdzonymi zderzakami, każda połączona $\mathrm{z}$ wózkiem napędowym za pomocą sworzni,

- przedział silnikowy z zaadaptowanym z kolei podwieszonej PIOMA CS 80 agregatem spalinowo-hydraulicznym utwierdzony w saniach łączących ze sobą zespoły napędowe.

W napędzie zastosowano przekładnię hydrostatyczną, która pełni jednocześnie rolę hamulca manewrowego. Lokomotywa ta znalazła zastosowane w kopalni węgla kamiennego LW Bogdanka S. A.

\subsection{Spalinowa kolej spągowa PIOMA VACAT}

Efektem współpracy KOMAG-u z FMG PIOMA S.A. oraz firmą VACAT Sp. z o.o. jest spalinowa kolej spągowa PIOMA VACAT (rys. 7). Cechą charakterystyczną kolei PIOMA-VACAT jest układ przeniesienia napędu. W zależności od potrzeb i warunków panujących w wyrobiskach wykorzystane może być cierne lub zębate sprzężenie kół napędowych z listwą napędową szyn jezdnych.

Do zbudowania ciągnika kolei spągowej wykorzystane zostały podzespoły ciągnika PIOMA CS 80, zabudowane na czterech modułach napędowych. Każdy moduł ma układ napędowy składający się z dwóch silników hydraulicznych, napędzających koła cierne i zębate oraz szczękowy układ hamulcowy wykorzystujący listwę cierną szyn. 

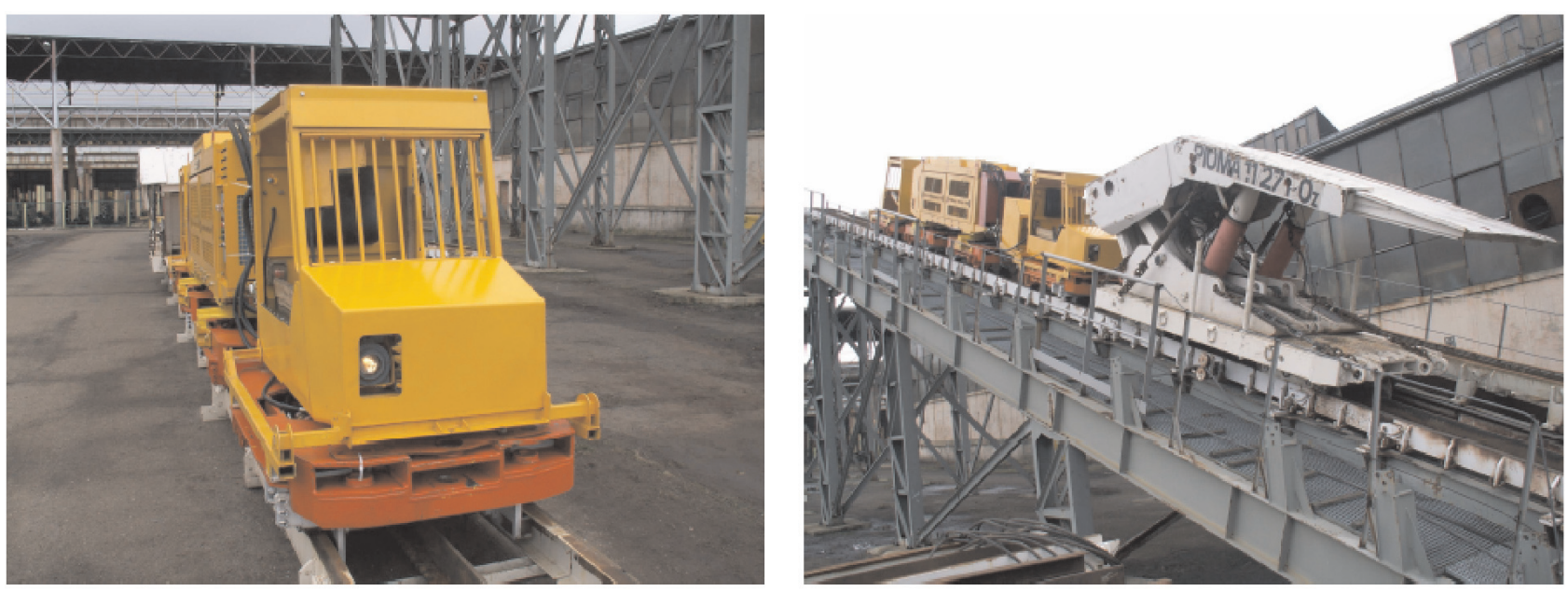

Fig. 7. PIOMA VACAT floor-mounted diesel railway [1]

Rys. 7. Spalinowa kolej spagowa PIOMA VACAT [1]

braking of transported assembly of high weight. Vertical position of driving wheels enabled eliminating component forces in a gear that would cause lifting of driving cars. Due to that transmission effectiveness is higher and transmission is more stable [1].

Wesoła Colliery is the first mine in which PIOMAVACAT floor-mounted diesel railway has been used.

\subsection{SKZ-81 rack-and-pinion railway}

Collaboration of KOMAG with RFM RYFAMA S.A. resulted in a development and construction of SKZ-81 rack railway. Transportation of loads (including complete powered roof supports) directly from shaft bottom to the longwall panel, without necessity of unloading, was the assumption for designing that railway system. Bearing in mind lowering of mine track construction costs it was decided to use existing tracks and to install rack bar at the inclined section of the track. Therefore, the train is equipped with two drives:

- friction drive to ride on the horizontal sections of the route,

- rack drive to ride on the workings inclined up to $30^{\circ}$.

A design of dual driving system has been developed in such a way that diesel engine system and pumping system are common for both actuating systems, i.e. for rack drive and rail drive. In the rack drive system, which was located between the two wheels sets GFT-
Pierwszą kopalnią, w której znalazła zastosowanie spalinowa kolej spągowa PIOMA-VACAT jest KWK Wesoła.

\subsection{Szynowa kolej zębata SKZ-81}

Współpraca KOMAG-u z RFM RYFAMA S.A. zaowocowała opracowaniem i wykonaniem szynowej kolei zębatej SKZ-81. Podstawowym założeniem przy opracowaniu tej kolei było zapewnienie możliwości transportu ładunków (w tym kompletnych sekcji obudowy zmechanizowanej) bezpośrednio od podszybia aż do wyrobiska ścianowego bez konieczności przeładunku. Mając na uwadze obniżenie kosztów wykonania trasy, postawiono za cel wykorzystanie istniejących torowisk kopalnianych dobudowując na odcinkach nachylonych listwę zębatą. W związku z tym kolej wyposażono w dwa napędy:

- adhezyjny do jazdy na poziomych odcinkach trasy, - zębaty do jazdy w wyrobiskach nachylonych do $30^{\circ}$. 
110 gear made by Rexroth was used. These transmissions are offered in several versions of the gear ratio; hence there is the possibility of sizing the gear ratio for the individual customer. Torque is directly attached to the driving wheel with bolts, which cooperates with the rack mounted along the track axis. The rail drive system uses two GFT-13 gears of the same company, each of which drives one wheel set located in one of two turning cars, being a part of driving car of the locomotive [1]. Rail rack railway has been implemented in Bielszowice Colliery.

\subsection{Lds-100K-EMA locomotive}

Lds 100K-EMA underground diesel locomotives have been developed in the result of collaboration between KOMAG-and ENERGO-MECHANIK Sp. z o.o. The locomotive is designed for transportation and maneuvering operations carried out in underground ore, salt and other mines of minerals in rooms with "a", "b" and "c" methane explosion hazard and class " $A$ " and " $\mathrm{B}$ " coal dust explosion hazard. In the drive system diesel engine is connected rigidly with hydrokinetic transmission and drives a reversion gear and front and rare intersecting axis gear. Main shafts of intersecting axis gear are at the same time the axes of wheel sets.

The Lds 100K EMA locomotive is fitted with an electronic system for a control of operational parameters, which stops the engine in the case of pressure decay of oil lubricating the engine, in the case of lack of pressure in the brake system or in the case of exceeding temperatures: of fluid cooling the engine, of exhaust gases, of oil in the hydraulic system. Apart from the central self-operating fire fighting system each cabin is equipped with a portable dry powder or carbon dioxide extinguisher [11].

The locomotives were used among others in Borynia Colliery and Jankowice Colliery.

\section{Development of mine diesel driver}

KOMAG Institute of Mining Technology continuously introduces modifications contributing to improvement of operation of the offered machines as well as it draws a special attention to the problems associated with operational safety of those machines.

Discussed in item 3, the mine diesel drive that is currently in use meets all requirements that such devices should satisfy, but it has huge potential for improvement of its design and operational features such as: reduction of weight and dimensions, elimination of hazards resulting from its operation.

It should be stated that mine drive units equipped with diesel engines operate in closed rooms such as mine workings and use the same stream of air that is used by the personnel working in mine. Assuming that diesel engine is supplied with fuel mixture having double amount of air $(\lambda=$ $2)$, burning of $1 \mathrm{~kg}$ of diesel oil means consumption of $30 \mathrm{~kg}$ of air. At average consumption of fuel by mine locomotive of about $20-30 \mathrm{~kg}$ per hour that means consumption of about $600-900 \mathrm{~kg}$ of air per hour and emission of the same amounts of exhaust
Podwójny system napędu rozwiązano w ten sposób, że zespół silnika spalinowego oraz zespól pompowy jest wspólny dla obu układów wykonawczych, to jest dla napędu zębatkowego i dla napędu szynowego [1]. Szynową kolej zębata wdrożono na kopalni KWK Bielszowice.

\subsection{Lokomotywa Lds-100K-EMA}

Lokomotywa dołowa spalinowa Lds-100K-EMA powstała w ramach współpracy KOMAG-u z firmą ENERGOMECHANIK Sp. z o.o.. Lokomotywa jest przeznaczona do prac transportowych i manewrowych w podziemiach kopalń węgla, rud, soli i innych minerałów użytkowych w pomieszczeniach ze stopniem „a”, „b” i „c” niebezpieczeństwa wybuchu metanu oraz klas „A” i „B" zagrożenia wybuchem pyłu węglowego. W układzie napędowym silnik spalinowy, połączony jest na sztywno przekładnię hydrokinetyczną, napędza poprzez przekładnię rewersyjną przednią oraz tylną przekładnię kątową. Wały główne przekładni kątowych są jednocześnie osiami zestawów kołowych.

Lokomotywa wyposażona jest w elektroniczny system nadzoru parametrów pracy wyłączający pracę silnika przy zaniku ciśnienia oleju smarującego silnik, braku ciśnienia w układzie hamulcowym, przekroczenia temperatury: cieczy chłodzącej silnik, spalin wylotowych, oleju w układzie hydraulicznym. [11].

Lokomotywy te znalazły zastosowanie miedzy innymi na kopalni KWK Borynia i KWK Jankowice.

\section{Rozwój górniczych napędów spalinowych}

Instytut Techniki Górniczej KOMAG w stale wprowadza modyfikacje przyczyniające się do poprawy warunków i jakości eksploatacji oferowanych maszyn, jak również zwraca baczną uwagę na zagadnienia związane $\mathrm{z}$ bezpieczeństwem eksploatacji.

Opisany powyżej i stosowany obecnie górniczy napęd spalinowy spełnia obowiązujące wymagania stawiane tego typu urządzeniom, przy czym istnieje w nim znaczny potencjał rozwojowy umożliwiający poprawę jego właściwości konstrukcyjne i eksploatacyjne takie jak: zmniejszenie masy

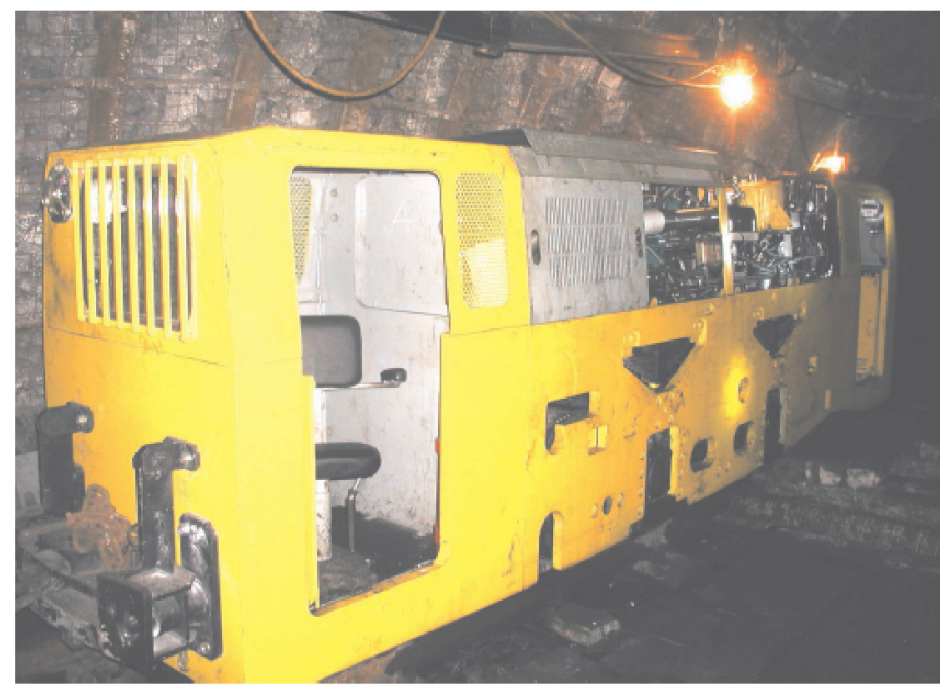

Fig. 9. Lds-100K-EMA locomotive in underground conditions [11] Rys. 9. Lokomotywa Lds-100K-EMA w warunkach dolowych [11] 
gases in confined space. Despite the fact that ventilation system is most important equipment in deep mines, the areas of worse air exchange, where concentration of toxic substances, emitted with exhaust gases can locally exceed permissible limits, can be found. Due to that, the problem of toxic substances emitted by mine diesel drives should be seriously taken into consideration both due to workers safety and due to future legal regulations that can be tougher as it happens in the motor industry.

Having that in mind, KOMAG Institute of Mining Technology takes actions in a development of mine drive units equipped with diesel engines that include the following R\&D projects:

- theoretical analysis of the phenomena associated with outflow of exhaust gases in conditions of operation of an engine in mining machines,

- theoretical analysis of thermal load to the engine driving mining machines, especially thermal load to the components of exhaust system,

- testing of engines used in the mining industry as regards thermal load to engine exhaust system and determination of areas where flames or sparks can appear,

- development of new automatic cooling of exhaust system and turbocharger that will guarantee maximal temperature of external surface below $150 \mathrm{oC}$,

- calculations of heat exchangers and the system for transfer of heat from exhaust system,

- development of intrinsically safe and flame arresting systems along the entire way of burning process from inlet system to exhaust system,

- tests and measurements of concentration of toxic substances in exhaust gases emitted by the engines driving mining machines,

- consideration of possibility of using innovative methods for reduction of toxic substances in exhaust gases.

The mentioned above projects are aiming at improvement of operational parameters of engine used in the mining industry as well as at improvement of work environment.

\section{Summary}

Within last years number of mine diesel drives in coal mining industry significantly increased. Further increase of application of such drives will continue especially in transportation machines. In the case of potentially explosive atmosphere the engine together with inlet and exhaust system must meet requirements of ATEX Directive. Fulfillment of these requirements causes a significant increase of the systems' weight and it is not good for operational conditions of the engine causing increase of flow resistance mainly by use of flame arresters. Despite many advantages the drives have a negative impact on environment mainly due to emission of exhaust gases (especially emission of toxic substances in exhaust gases).

That is why reduction of the hazard resulting from emission of exhaust gases in mine diesel drives is very important field of studies. Toxic substances emitted by drives are transported with airstream in a direction to outlet ventilation shaft i gabarytów zespołu, ułatwienie czynności obsługowych, zmniejszenie zagrożeń wynikających z jego eksploatacji.

Należy podkreślić, że górnicze zespoły napędowe, wyposażone w silniki spalinowe pracują w zamkniętych pomieszczeniach, jakimi są wyrobiska kopalń, korzystają przy tym z tego samego zasobu powietrza, z jakiego korzysta załoga kopalni. Przy teoretycznym założeniu, że silnik spalinowy maszyny górniczej zasilany jest mieszanką z dwukrotnym nadmiarem powietrza $(\lambda=2)$, spalenie $1 \mathrm{~kg}$ oleju napędowego oznacza pobranie z otoczenia ok. $30 \mathrm{~kg}$ powietrza. Przy średnim zużyciu paliwa wynoszącym dla lokomotywy górniczej ok. 20-30 kg na godzinę pracy, oznacza to pobranie w tym czasie ok. 600-900 kg powietrza i emitowanie w zamkniętej przestrzeni wyrobiska, podobnej masy spalin. Wprawdzie systemy wentylacji w kopalniach głębinowych należą do urządzeń pierwszoplanowych, tym niemniej mogą powstawać obszary o mniejszej wymianie powietrza, w których stężenie toksycznych składników spalin może miejscowo przekraczać dopuszczalne limity. W związku z tym zagadnienia emisji toksycznych substancji emitowanych przez górnicze napędy spalinowe muszą być poważnie brane pod uwagę, zarówno $\mathrm{z}$ uwagi na bezpieczeństwo załogi, jak i ze względu na przyszłe unormowania prawne w tym zakresie, które podobnie jak w motoryzacji mogą być coraz surowsze.

Mając powyższe na uwadze Instytut Techniki Górniczej KOMAG podejmuje działania w zakresie rozwoju górniczych zespołów napędowych wyposażonych w silniki spalinowe, w skład których wchodzą następujące prace badawcze:

- analiza teoretyczna zjawisk związanych z wypływem gazów spalinowych w różnych warunkach eksploatacji silnika w maszynach górniczych,

- analiza teoretyczna obciążenia cieplnego silnika napędzającego maszyny górnicze, w tym szczególnie obciążenia cieplnego elementów układu wylotowego,

- badania doświadczalne silników stosowanych w górnictwie w aspekcie obciążenia cieplnego układu wylotowego silnika i określenie obszarów występowania płomieni lub iskier,

- opracowanie nowego, bezobsługowego systemu chłodzenia układu wylotowego oraz turbosprężarki, gwarantującego utrzymanie maksymalnej temperatury zewnętrznej nieprzekraczającej $150^{\circ} \mathrm{C}$,

- obliczenia wymienników ciepła i systemu odprowadzenia ciepła z układu wylotowego,

- opracowanie systemu zabezpieczeń przeciwiskrowych i przeciwpłomieniowych na całej drodze wymiany ładunku silnika,

- badania doświadczalne stężenia toksycznych składników spalin silników napędzających maszyny górnicze,

- rozważenie możliwości zastosowania innowacyjnych rozwiązań do zmniejszenia emisji toksycznych składników spalin.

Wymienione zadania badawcze mają na celu poprawę parametrów eksploatacyjnych silników stosowanych w górnictwie, jak również poprawę środowiska pracy załóg górniczych. 
and passing roadways can be harmful to working people. Reduction of emission of harmful components of exhaust gases is advantageous not only as regards personnel health but also that can enable increasing number of diesel drives used in mine workings.

Paper reviewed/Artykut recenzowany

\section{Bibliography/Bibliografia}

[1] Drwięga A., Pieczora E., Suffner H.: „Nowe rozwiązania górniczych urządzeń transportowych z napędem spalinowym” monografia KOMTECH 2007: „Innowacyjne i bezpiezne maszyny i urządzenia dla górnictwa węgla kamiennego", Szczyrk 2007.

[2] Jaszczuk M., Kozieł A. [red]: „Scenariusze rozwoju technologicznego mechanizacji podstawowych procesów produkcyjnych w górnictwie węgla kamiennego", monografia KOMAG Gliwice 2008.

[3] Kaczmarczyk K., Dobrzaniecki P.: „Wybrane metody oczyszczania spalin możliwe do zastosowania w górniczych napędach spalinowych”, monografia KOMEKO 2010: „Paliwo - Bezpieczeństwo - Środowisko" Rytro 2010.

[4] Merkisz J., Lijewski P., Walasik S.: Analiza warunków pracy silników pojazdów o zastosowaniach pozadrgowych w aspekcie przepisów dotyczących emisji związków toksycznych spalin. Eksploatacja i Niezawodność nr 1/2010.

[5] Miareczko B., Gierasimiuk J.: „System oceny zgodności oraz kontroli wyrobów", http://www.ciop.pl.

[6] Pieczora E., Pawlicki D., Kaczmarczyk K., Dobrzaniecki P., Suffner H.: Nowe rozwiązania dołowych lokomotyw spalinowych opracowane w CMG KOMAG. Monografia KOMTECH 2006: „Innowacyjne i Bezpieczne Systemy Mechanizacyjne do Eksploatacji Surowców Mineralnych" Zakopane 2006.

[7] Pieczora E.: „Napęd spalinowy do pojazdów górniczych eksploatowanych w podziemnych wyrobiskach zagrożonych wybuchem pyłu i metany”, monografia „Napędy i sterowanie 2001", Gdańsk 2001.

[8] Rozporządzeniu Ministra Gospodarki z dnia 28 czerwca 2002 w sprawie bezpieczeństwa i higieny pracy, prowadzenia ruchu oraz specjalistycznego zabezpieczenia przeciwpożarowego w podziemnych zakładach górniczych (Dz. U. Nr 139, poz. 1169) wraz ze zmianą wprowadzoną rozporządzeniem Ministra Gospodarki z dnia 9 czerwca 2006 r. (Dz. U. Nr 124, poz. 863).

[9] Rozporządzenie Ministra Gospodarki z dnia 20 grudnia 2005 r. w sprawie zasadniczych wymagań dla maszyn i elementów bezpieczeństwa (Dz.U. Nr 259, poz. 2170)

[10] Rozporządzenie Ministra Gospodarki z dnia 22 grudnia 2005 r. w sprawie zasadniczych wymagań dla urządzeń i systemów ochronnych przeznaczonych do użytku w przestrzeniach zagrożonych wybuchem (Dz.U. z 2005 r. nr 263, poz. 2203) .

[11] Suffner H., Dobrzaniecki P., Budzyński Z.: „Nowoczesne lokomotywy dołowe produkcji Energo-Mechanik Sp. z o. o.”, Transport przemysłowy, 3(29)/2007.

\section{Podsumowanie}

W ostatnich latach nastąpiło znaczące zwiększenie liczby górniczych napędów spalinowych w górnictwie węgla kamiennego. Prognozowany jest dalszy wzrost zastosowań napędów tego typu, w szczególności urządzeniach transportowych z napędem spalinowym. W przypadku atmosfery potencjalnie wybuchowej, silnik wraz z układem dolotowym i wylotowym musi spełnić wymagania Dyrektywy ATEX. Spełnienie tych wymagań powoduje znaczne zwiększenie gabarytów oraz masy tych układów i nie wpływa korzystnie na warunki pracy silnika, powodując zwiększenie oporów przepływu, czego powodem są głównie przerywacze płomienia. Pomimo wielu zalet napędy te powodują negatywne oddziaływanie na warunki środowiskowe, główne w postaci emisji spalin (a zwłaszcza zawartych w nich toksycznych składników).

Bardzo ważnym obszarem działań w obrębie górniczych napędów spalinowych jest zagadnienie zmniejszenia zagrożenia wynikającego z emisji toksycznych składników spalin. Emitowanie poprzez napędy związki toksyczne unoszone są wraz prądem powietrza w kierunku szybu wydechowego, przemierzając wyrobiska korytarzowe oddziałują szkodliwie na pracują tam załogę, Obniżenie emisji szkodliwych składników spalin nie tylko ma korzystny wpływ na załogę górniczą, ale dostarczy również możliwość zwiększenia liczby napędów spalinowych w wyrobiskach górniczych.

Mr. Marek Brzeżański, DSc., DEng. - Deputy Manager of the Institute and Internal Combustion Engines at Cracov University of Technology.

Dr hab. inż. Marek Brzeżański - wicedyrektor Instytutu Pojazdów Samochodowych i Silników Spalinowych Politechniki Krakowskiej.

e-mail: mbrzez@usk.pk.edu.pl

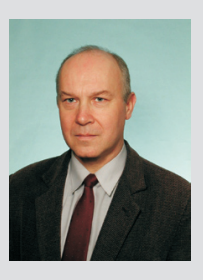

Mr. Edward Pieczora, DEng.- Deputy Director for Technical Development, KOMAG Institute of Mining Technology, Gliwice.

Dr inż. Edward Pieczora - zastępca dyrektora ds Rozwojowych, Instytut Techniki Górniczej KOMAG, Gliwice.

e-mail: epieczora@komag.eu

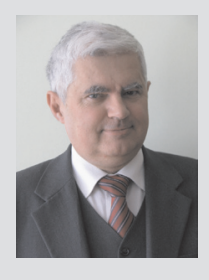

Mr. Krzysztof Kaczmarczyk, MEng.-- KOMAG Institute of Mining Technology, Gliwice.

Mgr inż. Krzysztof Kaczmarczyk - Instytut Techniki Górniczej KOMAG, Gliwice.

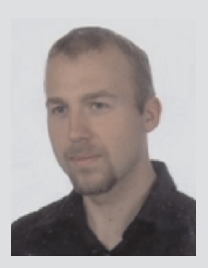

